\title{
Organophosphorus pesticides exhibit compound specific effects in rat precision-cut lung slices (PCLS): mechanisms involved in airway response, cytotoxicity, inflammatory activation and antioxidative defense
}

\author{
Jonas Tigges $^{1} \cdot$ Franz Worek $^{1} \cdot$ Horst Thiermann ${ }^{1} \cdot$ Timo Wille $^{1,2}$ (D)
}

Received: 10 August 2021 / Accepted: 28 October 2021 / Published online: 15 November 2021

(c) The Author(s) 2021

\begin{abstract}
Organophosphorus compound pesticides (OP) are widely used in pest control and might be misused for terrorist attacks. Although acetylcholinesterase (AChE) inhibition is the predominant toxic mechanism, OP may induce pneumonia and formation of lung edema after poisoning and during clinical treatment as life-threatening complication. To investigate the underlying mechanisms, rat precision-cut lung slices (PCLS) were exposed to the OP parathion, malathion and their biotransformation products paraoxon and malaoxon (100-2000 $\mu \mathrm{mol} / \mathrm{L})$. Airway response, metabolic activity, release of LDH, cytokine expression and oxidative stress response were analyzed. A concentration-dependent inhibition of airway relaxation was observed after exposure with the oxon but not with the thion-OP. In contrast, cytotoxic effects were observed for both forms in higher concentrations. Increased cytokine expression was observed after exposure to parathion and paraoxon (IL6, GM-CSF, MIP-1 $\alpha$ ) and IL-6 expression was dependent on NFKB activation. Intracellular GSH levels were significantly reduced by all four tested OP but an increase in GSSG and HO-1 expression was predominantly observed after malaoxon exposure. Pretreatment with the antioxidant $N$-acetylcysteine reduced malaoxon but not paraoxon-induced cytotoxicity. PCLS as a 3D lung model system revealed OP-induced effects depending on the particular OP. The experimental data of this study contribute to a better understanding of OP toxicity on cellular targets and may be a possible explanation for the variety of clinical outcomes induced by different OP.
\end{abstract}

Keywords Organophosphates $\cdot$ PCLS $\cdot$ Inflammation $\cdot$ Oxidative stress $\cdot$ Bronchoconstriction

\begin{tabular}{llll}
\multicolumn{2}{l}{ Abbreviations } & HO-1 & Heme oxygenase-1 \\
ACh & Acetylcholine & IC50 & Inhibitory concentration 50\% \\
AChE & Acetylcholinesterase & IKK & IKB kinase \\
DMEM & Dulbecco's Modified Eagle's Medium & JNK & C-Jun N-terminal kinase \\
ERK & Extracellular-signal regulated kinases & ROS & Reactive oxygen species \\
GM-CSF & Granulocyte-macrophage colony-stimulating & IL-6 & Interleukin-6 \\
& factor & LDH & Lactate-dehydrogenase \\
GSH & Glutathione & LPS & Lipopolysaccharide \\
GSSG $\quad$ Glutathione disulfide & MAPK & Mitogen-activated protein kinase \\
GST & Glutathione-S-transferase & MFI & Mean fluorescence intensity \\
& MIP-1A & Macrophage inflammatory protein 1A \\
\hline $\begin{array}{l}\text { Timo Wille } \\
\text { TimoWille @ bundeswehr.org }\end{array}$ & NAC & N-Acetylcysteine \\
Bundeswehr Institute of Pharmacology and Toxicology, & NFKB & Nuclear factor 'kappa-light-chain-enhancer' of \\
Neuherbergstrasse 11, 80937 Munich, Germany & OP & activated B-cells \\
Present Address: Department CBRN Medical Defence, & PCLS & Organophosphorus compound pesticides \\
Bundeswehr Medical Academy, Ingolstädter Str. 240, & PMSF & Phenylmethylsulfonylfluoride \\
80939 Munich, Germany & SEM & Standard error of the mean
\end{tabular}




$\begin{array}{ll}\text { SOD } & \text { Superoxide dismutase } \\ \text { STAT3 } & \begin{array}{l}\text { Signal transducers and activators of transcrip- } \\ \text { tion } 3\end{array} \\ \text { VEGF } & \text { Vascular endothelial growth factor }\end{array}$

\section{Introduction}

Organophosphorus compound pesticides (OP) are a class of highly toxic substances commonly used for crop protection. The widespread use and easy access resulted in high numbers of (self-) poisonings during the past decades (Peter et al. 2014; Eddleston et al. 2005). A conservative estimate suggests more than 100.000 death per year from pesticide self-poisoning worldwide, accounting for $13.7 \%$ of global suicides (Mew et al. 2017).

OP like parathion and malathion require biotransformation by cytochrome P450 enzymes to obtain the more toxic oxon-forms (Fukuto 1990; Eyer et al. 2003). The activated OPs exhibit acute toxicity via covalent binding to the active site of the AChE, leading to its inhibition. The subsequent accumulation of acetylcholine (ACh) at the acetylcholine receptor leads to a cholinergic crisis characterized by a toxidrome of muscarinic and nicotinic signs involving miosis, salivation, bronchospasm, bronchorrhea, muscular dysfunction and respiratory paralysis (Holmstedt 1959; Johnson 1987).

Standard treatment involves application of atropine, to antagonize muscarinic effects, in combination with an oxime for reactivation of inhibited AChE (Worek et al. 2020; Hrabetz et al. 2013). Even if therapeutic steps are rapidly induced and the clinical signs of cholinergic crisis mitigate, OP-induced pneumonia poses a life-threatening complication (Kamat et al. 1989; Hrabetz et al. 2013). Apart from the common mechanism of AChE inhibition, some OP are suspected to induce toxic non-AChE dependent effects (Costa 2006). Clinical as well as experimental in vivo data have shown effects of OP exposure on lung tissue indicating direct toxic effects and an interaction with the immune system (Hulse et al. 2014; Nambiar et al. 2007; Hrabetz et al. 2013). Due to the complexity of the pulmonary system, investigation of the underlying mechanisms is challenging. For the purpose of gas exchange, breathing mechanics and host defense, more than 50 different cell types are present in the lung that act together in a well-balanced composition (Travaglini et al. 2020). Due to limitations in the number of different cell types that can be cultured together, cell-cell interactions and matrix effects that may arise in vivo during lung damage cannot be studied in in vitro cell culture experiments (Liu et al. 2019). As an intermediate step between in vitro cell culture investigations and in vivo studies, precision-cut lung slices (PCLS) as an ex vivo tool are used. The viable lung tissue represents the whole complexity of the organ including all resident cell types in their natural spatial composition (Liberati et al. 2010) and has the potential to substantially reduce the number of in vivo experiments with regard to the 3R principle (Russel and Burch 1959). Due to advantages in standardized preparation and tissue culture, PCLS are frequently used as versatile tool for the investigation of cytotoxic effects, inflammatory activation or alterations of the redox system (Henjakovic et al. 2008; Sauer et al. 2014; Behrsing et al. 2013; Lauenstein et al. 2014). Conservation of the natural lung architecture alongside with presence of viable airways, surrounded by a functioning smooth muscle layer, enables the analysis of compound induced effects on airway response and, therefore, the investigation of novel treatment strategies for diseases like asthma or COPD (Herbert et al. 2019; Martin et al. 1996; Wohlsen et al. 2003).

Among the most frequently studied OP are parathion (WHO classification extremely hazardous; class 1A), malathion (WHO classification slightly hazardous; class III) and their respective biotransformation products paraoxon and malaoxon. We, therefore, used these four compounds to study their effects on airway response, cytotoxicity, inflammatory cytokine expression, alterations of the redox system and intracellular signaling cascades in PCLS. These investigations shed light on potential targets for future improvements in the treatment of OP poisoned patients.

\section{Methods}

\section{Chemicals}

For Tyrode buffer preparation, $2.68 \mathrm{mmol} / \mathrm{L} \mathrm{KCl}$ (Carl Roth, Karlsruhe, Germany), $1.05 \mathrm{mmol} / \mathrm{L} \mathrm{MgCl}_{2} \cdot 6 \mathrm{H}_{2} \mathrm{O}$ (Sigma Aldrich, St. Louis, USA), $0.42 \mathrm{mmol} / \mathrm{L} \mathrm{NaH}_{2} \mathrm{PO}_{4} \cdot 2 \mathrm{H}_{2} \mathrm{O}$ (Merck KGaA, Darmstadt, Germany), $137 \mathrm{mmol} / \mathrm{L}$ $\mathrm{NaCl}$ (Carl Roth), $1.8 \mathrm{mmol} / \mathrm{L} \mathrm{CaCl} \cdot 2 \mathrm{H}_{2} \mathrm{O}$ (Carl Roth), $22 \mathrm{mmol} / \mathrm{L} \mathrm{NaHCO}_{3}$ (Carl Roth) and $5.5 \mathrm{mmol} / \mathrm{L}$ glucose monohydrate (Merck KGaA) were dissolved in double-distilled water and $\mathrm{pH}$ was adjusted to 7.4 by carbogen gassing. PCLS were cultured in Dulbecco's Modified Eagle's Medium/Nutrient mixture F12 (1:1) without phenol red and L-glutamine (DMEM/F-12; Sigma-Aldrich) supplemented with $1 \%$ Penicillin/Streptomycin (Sigma-Aldrich) and $0.1 \%$ Gentamycin (Thermo Fisher, Waltham, USA). The low melting point agarose was purchased from Sigma-Aldrich. The OP parathion, paraoxon, malathion and malaoxon were purchased from LGC standards (London, United Kingdom) and stock-solutions $(0.1 \mathrm{~mol} / \mathrm{L})$ were prepared in acetonitrile (Merck KGaA). For bronchoconstriction experiments, a stock solution $(0.1 \mathrm{~mol} / \mathrm{L}$ in DMEM/F-12) of ACh (Sigma Aldrich) was prepared and stored at $-80^{\circ} \mathrm{C}$. The working solution $(50 \mu \mathrm{mol} / \mathrm{L}$ in cell culture medium) was freshly 
prepared on the day of the experiment. Lysis solution for intracellular protein, cytokine and heme oxygenase 1 (HO1) detection was prepared using phosphate-buffered saline (Sigma-Aldrich) supplemented with $0.1 \%$ Triton-X 100 (Sigma-Aldrich) and cOmplete ${ }^{\mathrm{TM}}$ EDTA-free protease inhibitor (Roche, Basel, Switzerland).

\section{Animals}

Male Wistar rats were purchased from Charles River Laboratories (Sulzfeld, Germany) and kept in a standard animal housing unit providing an automated $12 \mathrm{~h}$ light/dark cycle and air condition, as described in Herbert et al. (2017). Animals were fed with a standard diet and drinking water ad libitum. Upon arrival in the animal housing, rats were kept for at least seven days before using them for PCLS preparation to allow a proper acclimatization (final weight 300-500 g). All experiments were in accordance with the German Animal Welfare Act of 18th May 2006 (BGB1, I S. 1206, 1313) and the European Parliament and Council Directive of 22nd September 2010 (2010/63/EU).

\section{PCLS preparation}

For preparation of PCLS, a procedure as described previously (Herbert et al. 2017) with some modifications was applied. Briefly, rats were anesthetized by intraperitoneal injection of $75 \mathrm{mg} / \mathrm{kg}$ ketamine (Ketavet $100 \mathrm{mg} / \mathrm{mL}$, zoetis Deutschland GmbH, Berlin, Germany) and $10 \mathrm{mg} /$ $\mathrm{kg}$ xylazine (Xylasel $20 \mathrm{mg} / \mathrm{mL}$; Selectavet Dr. Otto Fischer GmbH, Weyarn-Holzolling, Germany) and sacrificed by exsanguination. Low melting point agarose $(1.5 \%$ in DMEM/F-12) was gently heated until boiling and cooled to $37^{\circ} \mathrm{C}$. Lungs were filled with agarose solution until the lung lobules were entirely enfolded. Afterwards, the lung was removed from the thoracic cavity and cooled on ice for $10 \mathrm{~min}$, followed by additional storage for $20 \mathrm{~min}$ in $4{ }^{\circ} \mathrm{C}$ pre-cooled DMEM/F-12 to allow agarose solidification. Subsequently, tissue cylinders with a diameter of $8 \mathrm{~mm}$ were generated using a biopsy punch. The cylinders were sliced into 250-300 $\mu \mathrm{m}$ thick PCLS using a Krumdieck Tissue Slicer (Alabama Research and Development, Munford, USA) with ice-cold Tyrode buffer ( $\mathrm{pH} 7.4$ ) as slicing medium. Slicing medium was changed after five cores and PCLS were collected in pre-cooled DMEM/F-12 until the slicing procedure was finished for all slices. Afterwards, all PCLS were placed in an incubator (HeraCell 240i; Thermo Fisher Scientific) at $37^{\circ} \mathrm{C}$ and $5 \% \mathrm{CO}_{2}$ on a shaker to enable washout of cellular debris and agarose from large airways. The cell culture medium was exchanged every $30 \mathrm{~min}$ for $1.5 \mathrm{~h}$ and afterwards every $60 \mathrm{~min}$ for another $2 \mathrm{~h}$. PCLS were held at $37{ }^{\circ} \mathrm{C}$ and $5 \% \mathrm{CO}_{2}$ until experimental use at the next day.

\section{Evaluation of bronchoconstriction}

PCLS were removed from the incubator and weighted with steel wires in a 24-well plate to prevent floating and were then transferred to the microplate-holder of an inverted microscope (Axio Observer D1, Carl Zeiss AG, Oberkochen, Germany) with an AxioCam HSm camera (Carl Zeiss AG, Germany). Using the AxioVision software (Version 4.8.2.0, Carl Zeiss AG), airway cross sections were observed for signs of vitality such as beating cilia and spontaneous muscle constrictions. At first, the initial airway area was assessed. Afterwards either the solvent control acetonitrile (1\%) or the OP $(0.001-100 \mu \mathrm{mol} / \mathrm{L})$ was added to the slices. After $3 \mathrm{~min}$ of incubation time of the OP, ACh $(0.5 \mu \mathrm{mol} / \mathrm{L}$ final concentration) was added directly into the culture medium. 2 min after ACh application, a second picture was taken to evaluate time-dependent airway constriction. After $60 \mathrm{~min}$, airway relaxation was calculated using the AxioVision software. Relaxation efficacy of solvent exposed slices was set as $100 \%$ and response of all OP-exposed PCLS was related to that value.

\section{Exposure of PCLS with OP compounds}

For exposure of PCLS with the OP parathion, paraoxon, malathion or malaoxon, dilutions in DMEM/F-12 were prepared freshly before each experiment, obtaining the final concentrations for exposure between 100 and $2000 \mu \mathrm{mol} / \mathrm{L}$. Acetonitrile $(<1 \%$ for relaxation experiments and $<2 \%$ in all other experiments) was used as solvent control and was chosen as it shows low effects on AChE inhibition in human erythrocyte membranes (IC50 of 2.8\%) compared to other frequently used solvents such as DMSO (IC50 of 1.1\%). In addition, current unpublished work points towards a lower cytotoxicity of acetonitrile in comparison to DMSO, ethanol or methanol in PCLS. Culture medium was replaced by OP-containing medium and PCLS were incubated for 8 or $24 \mathrm{~h}$ under standard cell culture conditions $\left(37^{\circ} \mathrm{C} ; 5 \% \mathrm{CO}_{2}\right)$.

\section{Analysis of PCLS viability and cell death}

To detect effects of OP on PCLS viability, an Alamar Blue assay (Invitrogen, Carlsbad, USA) was performed. The Alamar Blue assay is based on the reduction of resazurin to the fluorescent dye resorufin by metabolically active cells and, therefore, serves as marker for cellular viability. After OP exposure (100-2000 $\mu \mathrm{mol} / \mathrm{L})$, PCLS were incubated with Alamar Blue reagent for $2 \mathrm{~h}$ at $37^{\circ} \mathrm{C}$, and fluorescence intensity was detected using a plate-reading photometer (Tecan Infinite 220 PRO, Tecan Group Ltd., Mennedorf, Switzerland) at excitation wavelength of $560 \mathrm{~nm}$ and emission wavelength of $590 \mathrm{~nm}$. Signal intensity was referred to the respective solvent control acetonitrile $(<2 \%)$. To detect 
effects of $N$-acetylcysteine (NAC) on PCLS viability, lung slices were pre-treated with $5 \mathrm{mmol} / \mathrm{L}$ NAC (Sigma-Aldrich) in DMEM/F-12 for $4 \mathrm{~h}$, and afterwards the medium was replaced by the OP-containing exposure medium for $24 \mathrm{~h}$. For determination of cytotoxicity, an LDH (lactate dehydrogenase) assay was performed (Cytotoxicity detection $\mathrm{Kit}^{\mathrm{PLUS}}$, Roche), detecting LDH activity in the PCLS supernatant that is released from the cells during cell death. After OP exposure, supernatant was transferred into one well of a 96-well plate. Freshly prepared reaction mix, as described in the manufacturer's instructions, was added to the wells and incubated for $15 \mathrm{~min}$ at room temperature. Absorbance was detected at $490 \mathrm{~nm}$ and corrected by the reference wavelength of $605 \mathrm{~nm}$. Cytotoxicity was calculated as \% of the absorbance induced by the lysis solution (positive control) provided in the assay kit.

\section{Analysis of protein content by BCA}

The amount of protein in the PCLS after OP exposure $(100-1500 \mu \mathrm{mol} / \mathrm{L})$ was assessed as marker for tissue destruction and as reference for cytokine and HO-1 expression in the sample. After exposure, three PCLS per substance and concentration were sonicated on ice in an Eppendorf cup with $350 \mu \mathrm{L}$ of lysis buffer using a Bandelin Sonopuls Homogenizer $(3 \times 5 \mathrm{~s} ; 30 \%$ amplitude) (Bandelin electronic GmbH \& Co. KG, Berlin, Germany). Sonicated samples were centrifuged $\left(15,000 \times g, 20 \mathrm{~min}, 4^{\circ} \mathrm{C}\right)$ and supernatant was transferred into an Eppendorf tube. For protein detection, an Uptima BC Assay kit (Interchim, Montluçon, France) was applied according to the manufacturer's instructions. Absorbance was detected at $562 \mathrm{~nm}$ using a plate-reading photometer (Tecan Infinite 220 PRO, Tecan Group Ltd.). The protein concentration was then related to a non-OP exposed, solvent control.

\section{Cytokine expression evaluated by bioplex assay}

To evaluate immunomodulatory effects of the OP (100-1800 $\mu \mathrm{mol} / \mathrm{L})$ on PCLS, cytokines released into the PCLS supernatant and intracellular concentrations were detected using a Bio-Plex Pro ${ }^{\mathrm{TM}}$ Rat Cytokine 23-Plex Assay, analyzed on a BioPlex 200 system (Bio-Rad Laboratories, Hercules, USA). Lipopolysaccharide (LPS, $100 \mathrm{ng} /$ $\mathrm{mL}$ in DMEM/F12) served as positive control. Intracellular protein was extracted as described in "Analysis of protein content by BCA". The PCLS supernatant was removed and supplemented with protease inhibitor cocktail solution. All samples were snap-frozen in liquid nitrogen and stored at $-80{ }^{\circ} \mathrm{C}$ until further use in the bioplex system. The bioplex assay was performed according to the manufacturer's protocol with washing steps performed on a HydroFlex microplate washer (Tecan Group Ltd.). Cytokine concentrations of each sample were calculated using the provided assay standards. After normalization to the protein concentration, total amount of cytokines in the PCLS supernatant and cytosol was combined to receive the overall cytokine expression per mg of tissue protein. Cytokine expression is shown as \% of the solvent control acetonitrile.

\section{Glutathione detection assay}

For the detection of the reduced (GSH) and oxidized (GSSG) form of glutathione in PCLS, a GSH/GSSG-Glo ${ }^{\mathrm{TM}}$ Assay (Promega, Madison, USA) was used as described in the manufacturer's instructions with slight modifications. After OP exposure (100-1500 $\mu \mathrm{mol} / \mathrm{L})$ each PCLS was transferred into one well of a white 96 -well plate (Thermo Fisher Scientific). $50 \mu \mathrm{L}$ of lysis reagent (total GSH lysis reagent or oxidized GSH lysis reagent) was added directly to the PCLS and incubated for $5 \mathrm{~min}$ at room temperature on a plate shaker $(850 \mathrm{rpm})$ to allow tissue lysis. $50 \mu \mathrm{L}$ of Luciferin Generation solution was added to each well and incubated for $30 \mathrm{~min}$ at room temperature in the dark. Afterwards, $100 \mu \mathrm{L}$ Luciferin Detection Reagent was added and incubated for $15 \mathrm{~min}$. Luminescence was detected using a plate-reading photometer (Tecan Infinite 220 PRO, Tecan Group Ltd.). GSH and GSSG concentrations are depicted as $\%$ of solvent control acetonitrile.

\section{Glutathione-s-transferase (GST) activity assay}

To detect effects of OP exposure $(100-1500 \mu \mathrm{mol} / \mathrm{L})$ on the GST activity, a colorimetric GST activity assay Kit (abcam, Cambridge, UK) was used. After OP exposure, three PCLS per substance and concentration were combined and sonicated ( $3 \times 5$ s $30 \%$ amplitude) in GST Assay Buffer. After centrifugation $\left(10,000 \times \mathrm{g}, 15 \mathrm{~min}, 4^{\circ} \mathrm{C}\right)$, the intracellular fraction was stored at $-80^{\circ} \mathrm{C}$ until further use. GST activity was analyzed as indicated in the manufacturer's instructions. Absorbance increase between 2 and 10 min was used to obtain GST activity that was afterwards referred to the solvent control acetonitrile.

\section{Superoxide dismutase (SOD) activity assay}

To detect effects of OP exposure on SOD activity in PCLS, a colorimetric Superoxide Dismutase Activity Assay Kit (abcam) was used. In this assay, superoxide is produced by a xanthine oxidase and metabolized into hydrogen peroxide and $\mathrm{O}_{2}$ by SOD. Superoxide anions react with WST-1 to produce a formazan dye with an absorbance maximum at $450 \mathrm{~nm}$. The higher the SOD activity is, the less superoxide is present in the sample and, therefore, formazan production is decreased. After OP exposure (100-1500 $\mu \mathrm{mol} / \mathrm{L})$, three PCLS per condition 
were combined in ice-cold SOD lysis buffer $(100 \mu \mathrm{mol} / \mathrm{L}$ Tris/HCl, pH 7.4 containing $0.5 \%$ Triton X-100 (SigmaAldrich), $5 \mathrm{mmol} / \mathrm{L} 2$-mercaptoethanol (Sigma-Aldrich) and $0.1 \mathrm{mg} / \mathrm{mL}$ phenylmethylsulfonylfluoride (PMSF; Roche). Samples were lysed on ice using a Bandelin Sonopuls Homogenizer $(3 \times 5 \mathrm{~s} ; 30 \%$ amplitude $)$. After centrifugation $\left(15,000 \times g, 10 \mathrm{~min}, 4{ }^{\circ} \mathrm{C}\right)$ sample supernatant was transferred into a fresh tube and snap frozen in liquid nitrogen. Samples were stored at $-80{ }^{\circ} \mathrm{C}$ until further use. SOD activity analysis was performed as described in the manufacturer's instructions. Thereof, SOD activity was calculated for each sample and related to the solvent control acetonitrile.

\section{HO-1 and IL-6 detection}

After OP exposure, three PCLS per substance and concentration were combined, intracellular protein fraction (HO-1 and IL-6) and supernatant (IL-6) were prepared as described in "Analysis of protein content by BCA" and stored at $-80^{\circ} \mathrm{C}$ until further use. For evaluation of nuclear factor 'kappalight-chain-enhancer' of activated B-cells (NF- $\kappa \mathrm{B}$ ) activation in OP-induced inflammatory activation, PCLS were exposed to parathion or the solvent control acetonitrile in the presence or absence of $10 \mu \mathrm{mol} / \mathrm{L}$ NF- $\mathrm{\kappa B}$ activation Inhibitor VI, benzoxanthiole compound (abcam) for $8 \mathrm{~h}$. DMSO (0.05\%) served as solvent control. HO-1 and IL-6 levels were evaluated using commercially available kits (Rat HO-1/HMOX1/ HSP32 ELISA Kit; novus biologicals, Littleton, USA and an ELISA Duo Set; R\&D Systems, Minneapolis, USA) and were corrected for the protein content of the sample. Results are shown as \% of the solvent control acetonitrile.

\section{Signaling pathway activation bioplex}

To analyze effects of OP exposure on signaling pathways, the intracellular fraction was analyzed using a bioplex system. Therefore, specific beads for phospho-c-Jun (Ser63), phospho-p38 MAPK (T180/Y182) and pospho-STAT3 (Tyr705) were used. After $8 \mathrm{~h}$ of exposure to $1000 \mu \mathrm{mol} / \mathrm{L}$ of the four OP, three PCLS per exposure were combined, washed with cell wash buffer, and lysed in tissue lysis buffer supplemented with $2 \mathrm{~mol} / \mathrm{L}$ PMSF (Roche) and $1 \times$ lysis buffer QG (Bioplex Cell Signaling Assay Kit). Samples were sonicated $(3 \times 5 \mathrm{~s} ; 30 \%$ amplitude), centrifuged $(15,000 \times g$, $20 \mathrm{~min}, 4^{\circ} \mathrm{C}$ ) and snap frozen in liquid nitrogen. Afterwards, samples were stored at $-80{ }^{\circ} \mathrm{C}$ until further use. The Bioplex assay was performed as described in the manufacturer's instructions using $200 \mu \mathrm{g} / \mathrm{mL}$ protein per sample. Afterwards, mean fluorescence intensity (MFI) was analyzed on a bioplex 200 system. MFI of the sample is shown as \% of the solvent control acetonitrile.

\section{Data analysis}

Data are presented as mean \pm standard error of the mean (SEM). Statistical analyses were performed using GraphPad Prism Version 5.04 (GraphPad Software, San Diego, USA). Differences to controls were determined by two-way ANOVA with Bonferroni multiple comparison test. Effects on airway relaxation and NF- $\mathrm{KB}$ inhibition were evaluated by one-way ANOVA with Dunnett's multiple comparison test. A $p$ value below 0.05 was considered statistically significant. ${ }^{*} p<0.05 ; * * p<0.01 ; * * * p<0.001$.

\section{Results}

\section{Effects of OP exposure on airway relaxation}

For the evaluation of OP effects on airway response, PCLS containing airways were exposed to parathion, paraoxon, malathion or malaoxon and airway relaxation was monitored $60 \mathrm{~min}$ after ACh stimulus $(0.5 \mu \mathrm{mol} / \mathrm{L})$. OP exposure without ACh did not result in an alteration of the airway area in the highest applied concentrations (control: $102 \pm 3 \%$; parathion: $113 \pm 3 \%$; paraoxon: $98 \pm 4 \%$; malathion: $104 \pm 3 \%$; malaoxon: $109 \pm 8 \%$ ). In addition, maximum constriction of the airway after ACh addition was not significantly different between the four tested OP in the highest applied concentrations (airway area after ACh addition: control: $53 \pm 9 \%$; parathion: $51 \pm 12 \%$; paraoxon: $45 \pm 9 \%$; malathion: $46 \pm 10 \%$; malaoxon: $50 \pm 8 \%$ ) and is comparable with other PCLS studies (Wigenstam et al. 2021; Herbert et al. 2017). Exposure with parathion or malathion in concentrations between 0.1 and $100 \mu \mathrm{mol} / \mathrm{L}$ had no significant effect on airway relaxation compared to the solvent control [mean relaxation efficiency $100 \mu \mathrm{mol} / \mathrm{L}$ : parathion (118\%, Fig. 1A); malathion (90\%, Fig. 1C)]. Airway relaxation after exposure to paraoxon (Fig. 1B) was significantly inhibited by concentrations from $0.1 \mu \mathrm{mol} / \mathrm{L}(-26 \%)$ to $10 \mu \mathrm{mol} / \mathrm{L}(-43 \%)$. Exposure to malaoxon (Fig. 1D) also led to a reduction in airway relaxation efficiency, that was significant after exposure to $1 \mu \mathrm{mol} / \mathrm{L}(53 \%)$ and $10 \mu \mathrm{mol} / \mathrm{L}(-20 \%)$. Negative values indicate a further increased airway constriction compared to 2 min of ACh incubation as reference value for initial airway constriction.

\section{Effects of OP exposure on PCLS viability}

To detect effects of OP exposure on the viability of PCLS, intracellular reducing power (Alamar Blue assay), release of $\mathrm{LDH}$ and the overall protein content were analyzed 


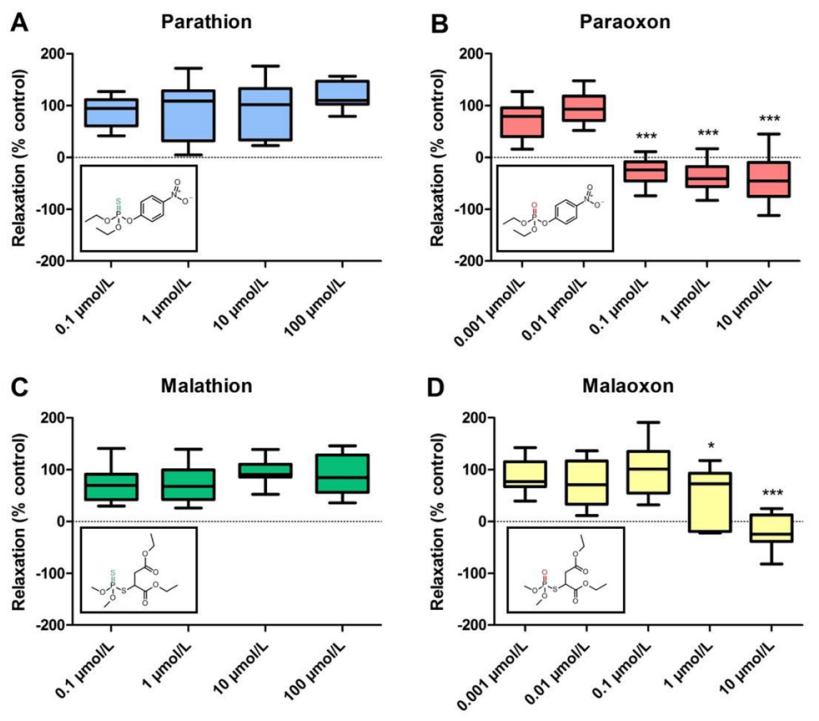

Fig. 1 Inhibitory effect of parathion, paraoxon, malathion and malaoxon on airway relaxation after acetylcholine stimulus. PCLS airways exposed for $3 \mathrm{~min}$ to parathion $(\mathbf{A})$, paraoxon $(\mathbf{B})$, malathion (C) or malaoxon (D) in different concentrations $(0.001-100 \mu \mathrm{mol} / \mathrm{L})$. Upon acetylcholine stimulus $(0.5 \mu \mathrm{mol} / \mathrm{L} ; 2 \mathrm{~min})$, airway constriction was recorded. Subsequent airway relaxation was evaluated after $60 \mathrm{~min}$. Relaxation of the control was set as $100 \%$. Boxplots show mean with minimum and maximum values. Asterisks indicate significant differences to the control $\left({ }^{*} p<0.05,{ }^{* * *} p<0.001 ; n=10\right.$ airways from at least three different animals) after $24 \mathrm{~h}$ of exposure with different OP concentrations (100-2000 $\mu \mathrm{mol} / \mathrm{L})$. In addition, we used the Alamar Blue assay and protein detection to exclude possible cytotoxic effects that can influence inflammation and oxidative stress after $8 \mathrm{~h}$ of OP exposure. OP exposure for $8 \mathrm{~h}$ results in a decrease of viability that was significant only in high concentrations for paraoxon $(2000 \mu \mathrm{mol} / \mathrm{L})$, malaoxon $(1600 \mu \mathrm{mol} / \mathrm{L})$ and malathion $(2000 \mu \mathrm{mol} / \mathrm{L})$ and detection of the corresponding protein content as marker for severe tissue damage indicated no significant differences to the solvent control for all four tested compounds (detailed viability data in Fig S1). After $24 \mathrm{~h}$ we made contrasting observations. Using an Alamar Blue assay, a decrease in resazurin reduction was observed for paraoxon, malathion and malaoxon (Fig. 2B-D), while no such effect was detectable after parathion exposure (Fig. 2A). Thereby, significant changes to the solvent control were observed at $1200 \mu \mathrm{mol} / \mathrm{L}$ paraoxon $(63 \pm 5 \%), 600 \mu \mathrm{mol} / \mathrm{L}$ malaoxon $(59 \pm 14 \%)$ and $1000 \mu \mathrm{mol} / \mathrm{L}$ malathion $(63 \pm 14 \%)$. Based on the viability, $\mathrm{EC}_{50}$ concentrations in a very similar range as the significantly different changes were calculated; i.e. $\sim 1400 \mu \mathrm{mol} / \mathrm{L}$ (paraoxon), $\sim 600 \mu \mathrm{mol} / \mathrm{L}$ (malaoxon) and $\sim 1100 \mu \mathrm{mol} / \mathrm{L}$ (malathion). A complete loss of viability was observed only after exposure to $\geq 1400 \mu \mathrm{mol} / \mathrm{L}$ malaoxon.

An increase in LDH was observed in the PCLS supernatant for several concentrations of paraoxon, malathion and malaoxon, whereas parathion induced a significant effect only in the highest applied concentration. Significant
Fig. 2 Effects of parathion, paraoxon, malathion and malaoxon on viability, cell death and protein content. PCLS were exposed for $24 \mathrm{~h}$ to different concentrations of parathion (A), paraoxon (B), malathion $(\mathbf{C})$ or malaoxon $(\mathbf{D})$ (10-2000 $\mu \mathrm{mol} / \mathrm{L})$. Viability was analyzed by Alamar Blue assay and effects on cellular death were evaluated by measurement of LDH release into PCLS supernatant. For detection of severe tissue destruction, intracellular protein content was detected by BCA assay $(\mathbf{E})$. Data are presented as \% of control (Alamar Blue assay and protein content) or as $\%$ of the positive control Triton$\mathrm{X}(\mathrm{LDH})$. Data are shown as mean \pm SEM. Asterisk indicate significant differences to control $(* p<0.05 ; * * p<0.01$; $* * * p<0.001 ; n=6$ PCLS from three different animals)
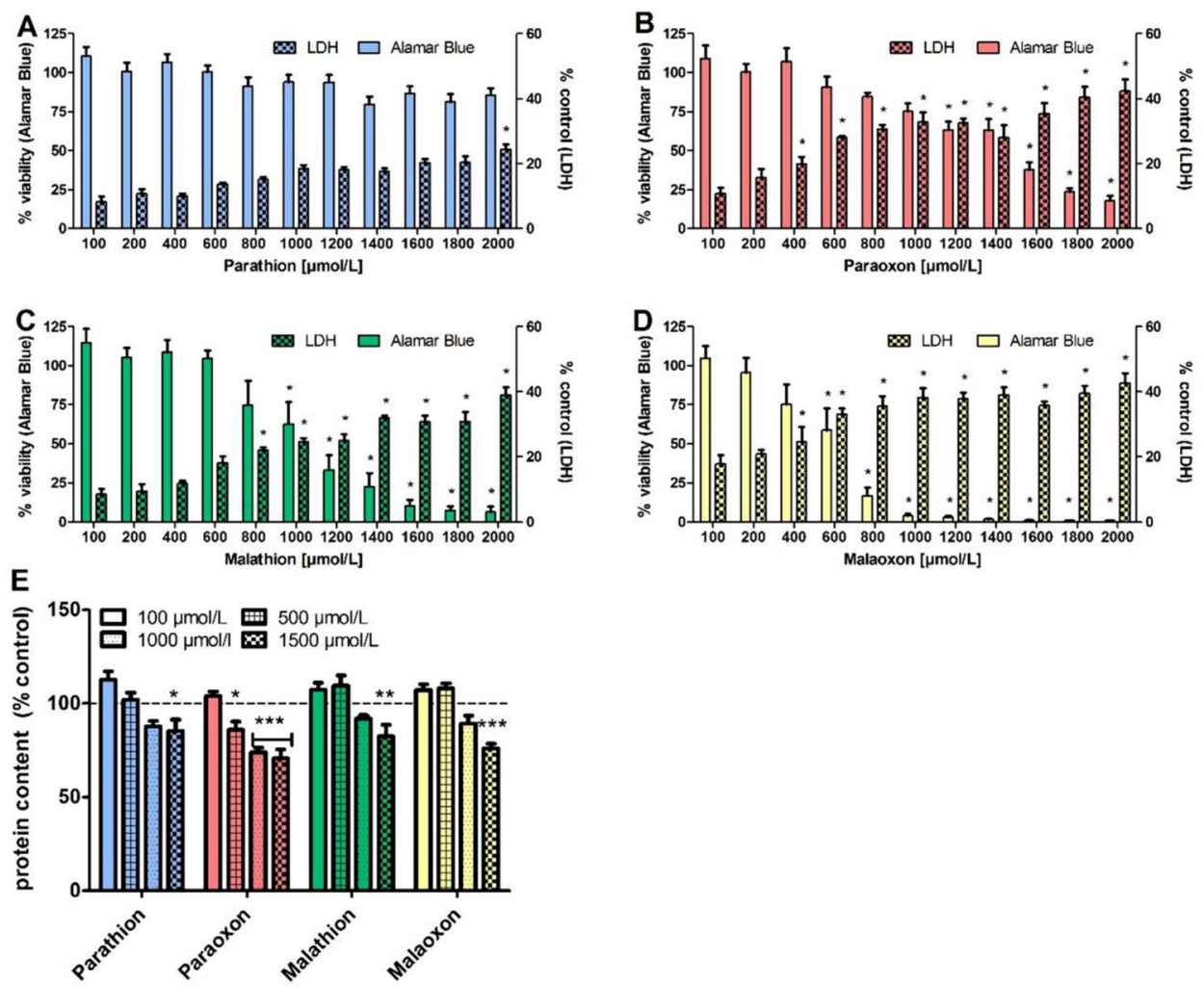
differences to the solvent control were observed at concentrations of $2000 \mu \mathrm{mol} / \mathrm{L}$ for parathion (Fig. $2 \mathrm{~A}$ ); $400 \mu \mathrm{mol} / \mathrm{L}$ for paraoxon (Fig. 2B), $800 \mu \mathrm{mol} / \mathrm{L}$ for malathion (Fig. 2C), and $400 \mu \mathrm{mol} / \mathrm{L}$ for malaoxon (Fig. 2D).

Detection of the protein content of the PCLS after OP exposure and subsequent tissue lysis serves as marker for severe tissue injury. Exposure to the four OP led to a decrease of protein content, that was significant for parathion $(85 \pm 4 \%)$, paraoxon $(70 \pm 5 \%)$, malathion $(83 \pm 6 \%)$ and malaoxon $(76 \pm 3 \%)$ at a concentration of $1500 \mu \mathrm{mol} / \mathrm{L}$ (Fig. 2E).

\section{Inflammatory activation in PCLS induced by OP}

For the detection of inflammatory activation in PCLS after OP exposure, an incubation period of $8 \mathrm{~h}$ was used to evaluate inflammatory activation without the bias of severe cytotoxicity and tissue damage that occurs after $24 \mathrm{~h}$ of exposure (Fig. 2). LPS (100 ng/mL) as positive control led to a stong expression of pro-inflammatory cytokines after $8 \mathrm{~h}$ of exposure (Fig. S2) and pilot tests to find concentration ranges for inflammatory activation revealed OP concentrations of $100,600,1200$ and $1800 \mu \mathrm{mol} / \mathrm{L}$ as suitable for cytokine detection.

Induction of IL-6 expression (Fig. 3A) was observed after exposure to parathion $(553 \pm 53 \%, p<0.001)$ and paraoxon $(225 \pm 35 \%, p<0.05)$ at concentrations of $1800 \mu \mathrm{mol} / \mathrm{L}$ and $1200 \mu \mathrm{mol} / \mathrm{L}$, respectively. In contrast, the expression of vascular endothelial growth factor (VEGF; Fig. 3C) was only increased after parathion exposure (up to $230 \pm 35 \%$; $1800 \mu \mathrm{mol} / \mathrm{L}, p<0.001$ ), while exposure to the other OP induced no statistically significant differences compared to the control. Expression of granulocyte-macrophage colony-stimulating factor (GM-CSF; Fig. 3D) was moderately upregulated by paraoxon $(166 \pm 15 \% ; 1200 \mu \mathrm{mol} / \mathrm{L}$, $p<0.05)$, parathion $(217 \pm 30 \% ; 1800 \mu \mathrm{mol} / \mathrm{L} ; p<0.001)$ and malathion $(160 \pm 5 \% ; 600 \mu \mathrm{mol} / \mathrm{L}, p<0.05)$ while no changes in GM-CSF expression were observed after exposure to malaoxon. Macrophage inflammatory protein (MIP-1 $\alpha$ ) expression (Fig. 3B) was significantly increased after exposure to parathion $(191 \pm 6 \% ; 1800 \mu \mathrm{mol} / \mathrm{L}$; $p<0.001)$ and paraoxon $(160 \pm 10 \% ; 1800 \mu \mathrm{mol} / \mathrm{L}$; $p<0.001)$.

\section{Cytokine expression after NFkB inhibition}

To analyze NFKB signaling pathway activation in OP-induced inflammation, parathion exposed PCLS $(1800 \mu \mathrm{mol} / \mathrm{L})$ were co-incubated with an NFkB inhibitor $(10 \mu \mathrm{mol} / \mathrm{L})$ and expression of IL-6 was analyzed. Cytokine expression was significantly increased to $451 \pm 39 \%(p<0.01$ vs. solvent control; Fig. 3E) after parathion exposure. Coincubation with the NFKB activation inhibitor resulted in
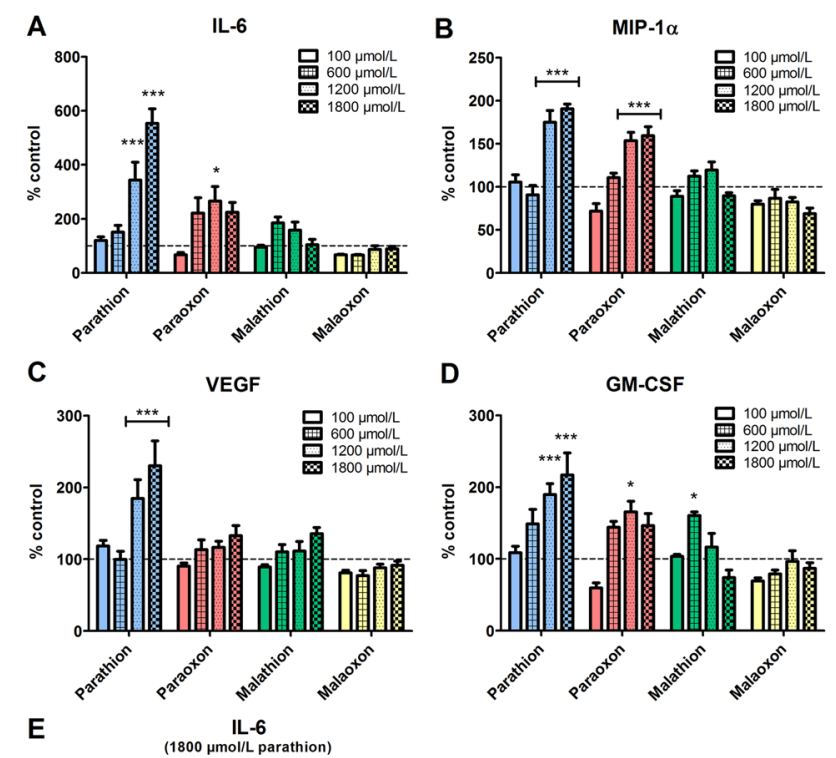

D GM-CSF

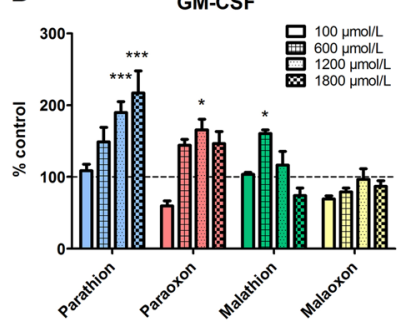

Fig. 3 Expression of cytokines in PCLS after parathion, paraoxon, malathion and malaoxon exposure. PCLS were exposed to increasing concentrations of paraoxon, parathion, malaoxon, malathion (100-1800 $\mu \mathrm{mol} / \mathrm{L}$ ) for $8 \mathrm{~h}$. Cytokine expression of IL-6 (A), MIP-1 $\alpha$ (B), VEGF (C) and GM-CSF (D) was detected in the supernatant and cytosolic fraction using a Bioplex-system and was afterwards combined to analyze the overall cytokine production. Observed concentrations are corrected for the protein content and are shown as fold increase of control (indicated by dashed line). For evaluation of NF- $\kappa \mathrm{B}$ activation, PCLS were exposed to parathion $(1800 \mu \mathrm{mol} / \mathrm{L})$ with or without addition of an NF- $\mathrm{BB}$ Activation Inhibitor (10 $\mu \mathrm{mol} / \mathrm{L} ; \mathbf{E})$. Interleukin-6 was detected in the supernatant and cytosolic fraction by ELISA, and afterwards combined to analyze the overall cytokine production. Data are shown as mean \pm SEM. Asterisk indicate significant differences to the control $\left({ }^{*} p<0.05\right.$; $* * p<0.01 ; * * * p<0.001 ; n=8$ samples from four different animals) Hash characters indicate significant differences to parathion exposure without inhibitor ( ${ }^{\# \#} p<0.01 ; n=8$ samples from four different animals)

a significant reduction of IL-6 expression to $231 \pm 36 \%$ ( $p<0.01$ vs. parathion exposed PCLS without inhibitor).

\section{Effects of OP exposure on oxidative stress response}

To detect effects of OP exposure on the cellular oxidative stress response, the levels of reduced glutathione (GSH) and oxidized glutathione (GSSG) were detected after $8 \mathrm{~h}$ of exposure. A decrease of intracellular GSH was observed after exposure to all four OP, resulting in a reduction to $17 \pm 1 \%$ (paraoxon); $49 \pm 4 \%$ (parathion); $30 \pm 6 \%$ (malaoxon) and $51 \pm 16 \%$ (malathion) at the 
Fig. 4 Effect of parathion, paraoxon, malathion and malaoxon exposure on reduced and oxidized glutathione content, GST- and SOD activity and expression of HO-1. PCLS were exposed for $8 \mathrm{~h}$ to different concentrations of paraoxon, parathion, malaoxon, malathion (100-1500 $\mu \mathrm{mol} / \mathrm{L})$. Afterwards the intracellular level of reduced (A) and oxidized (B) glutathione was detected. Furthermore, intracellular activity of GST (C) and SOD (D) was evaluated. Expression of intracellular HO-1 was evaluated by ELISA and corrected for the protein concentration. All results are shown as \% of control (indicated by dashed line). Data are shown as mean \pm SEM. Asterisk indicate significant differences to the control $(*<0.05$; $* * p<0.01 ; * * * p<0.001 ; n=6$ PCLS from three different animals (GST and SOD Activity Assay) $n=8$ PCLS from four different animals (GSH, GSSG, HO-1))
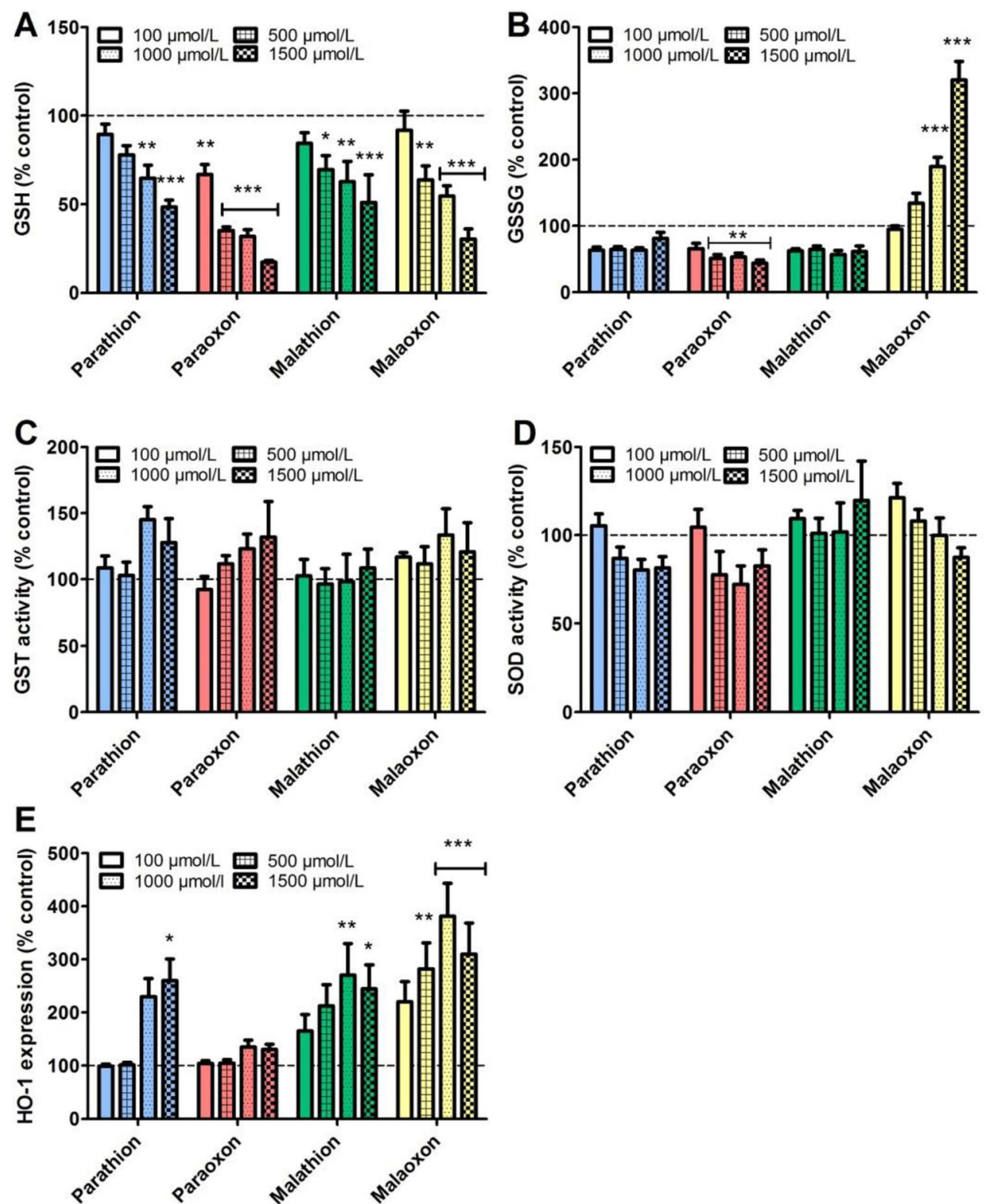

highest concentration of $1500 \mu \mathrm{mol} / \mathrm{L}$ (Fig. 4A). Detecting intracellular GSSG levels, a significant reduction after exposure to $1500 \mu \mathrm{mol} / \mathrm{L}$ of paraoxon $(44 \pm 5 \%)$ was observed while effects of parathion $(81 \pm 9 \%)$, and malathion $(62 \pm 8 \%)$ were not significant compared to the solvent control. In contrast, a dose-dependent, significant increase of GSSG after exposure to $1500 \mu \mathrm{mol} / \mathrm{L}$ malaoxon $(320 \pm 28 \% ; p<0.001)$ was detected (Fig. 4B). To evaluate whether the applied OPs influence the GST activity, which may affect intracellular GSH concentrations, a GST activity assay was performed. After $8 \mathrm{~h}$ of exposure, no statistically significant differences to the solvent control were found (Fig. 4C). Exposure to $1500 \mu \mathrm{mol} / \mathrm{L}$ of parathion, paraoxon, malathion and malaoxon resulted in an activity of $127 \pm 18 \% ; 132 \pm 27 \% ; 108 \pm 14 \%$ and $120 \pm 22 \%$, respectively. As superoxide formation plays a role in the maintenance of the redox system, SOD activity after $8 \mathrm{~h}$ of OP exposure was analyzed. SOD activity was not affected in PCLS after $8 \mathrm{~h}$ of exposure to the four OP at the highest concentration of $1500 \mu \mathrm{mol} / \mathrm{L}$ (Fig. 4D). For the detection of cellular reactions in response to a possible alteration of the redox system, expression of HO-1 was detected after $8 \mathrm{~h}$ of OP exposure (Fig. 4E). While exposure to paraoxon had no effect on HO-1 expression, exposure to $1500 \mu \mathrm{mol} / \mathrm{L}$ parathion resulted in a significantly increased expression $(261 \pm 40 \%)$. A statistically significant induction of HO-1 expression was observed after exposure to $1000 \mu \mathrm{mol} / \mathrm{L}$ of malathion $(270 \pm 59 \%$; 

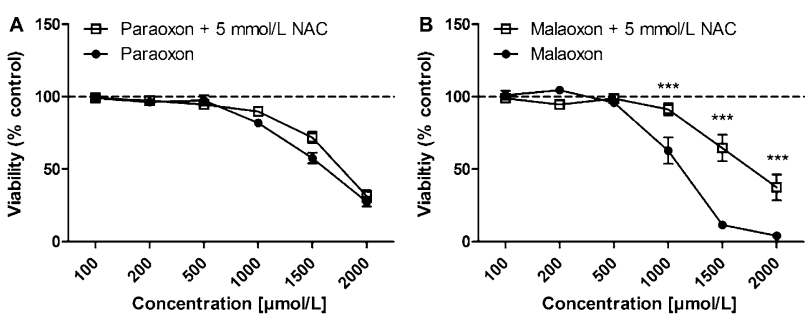

Fig. 5 Effects of $N$-acetylcysteine (NAC) pre-treatment on PCLS viability. PCLS were pre-treated with $5 \mathrm{mmol} / \mathrm{L}$ of NAC for $4 \mathrm{~h}$. Afterwards medium was replaced by paraoxon $(\mathbf{A})$ or malaoxon $(\mathbf{B})$ containing medium for $24 \mathrm{~h}$ and viability was analyzed by Alamar Blue assay. Viability is shown as \% of control (indicated by dashed line). Data are shown as mean \pm SEM. Asterisk indicate significant differences to PCLS without NAC pre-treatment $\left({ }^{*} p<0.05 ; n=6\right.$ PCLS from three different animals)

$p<0.01$ ), while exposure to malaoxon led to a maximal induction to $310 \pm 59 \%$ at $1500 \mu \mathrm{mol} / \mathrm{L}(p<0.001)$.

\section{Pre-treatment with NAC}

While no statistically significant effect of NAC pre-treatment on paraoxon induced cytotoxicity was observed, NAC pre-treatment significantly $(p<0.05)$ reduced the effects of malaoxon on PCLS viability at concentrations of $1000 \mu \mathrm{mol} / \mathrm{L}$ [ $63 \pm 9 \%$ (- NAC) vs. $91 \pm 4 \%$ (+NAC)]; $1500 \mu \mathrm{mol} / \mathrm{L}[11 \pm 2 \%(-\mathrm{NAC})$ vs. $65 \pm 9 \%(+\mathrm{NAC})]$ and $2000 \mu \mathrm{mol} / \mathrm{L}[4 \pm 1 \%(-\mathrm{NAC})$ vs. $37 \pm 9 \%(+\mathrm{NAC})]$ (Fig. 5).

\section{Signaling pathway activation after OP exposure}

To analyze effects of OP exposure on signaling pathways in PCLS, phosphorylation of p38-MAPK, STAT3 and c-Jun was detected using a bioplex assay. An exposure concentration of $1000 \mu \mathrm{mol} / \mathrm{L}$ was used to detect pathway activation without involvement of direct cytotoxic effects. Phosphorylated p38MAPK was significantly $(p<0.01)$ increased by parathion, malathion and malaoxon, which induced the strongest activation $(236 \pm 15 \%)$. In contrast, phosphorylation of STAT3 was significantly $(p<0.05)$ reduced by paraoxon $(22 \pm 5 \%)$, malathion $(42 \pm 4 \%)$ and malaoxon $(24 \pm 4 \%)$ while no significant reduction was observed after parathion exposure $(80 \pm 9 \%)$. Phosphorylation of c-Jun was significantly induced only by malaoxon $(182 \pm 19 \%$; $p<0.01$ ), while exposure to the other compounds did not induce a significant alteration of phosphorylation status (Fig. 6).

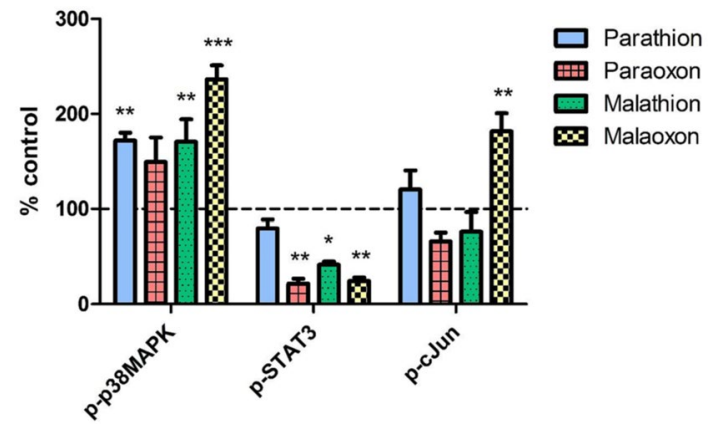

Fig. 6 Phosphorylation of signaling pathways after OP exposure. PCLS were exposed to $1000 \mu \mathrm{mol} / \mathrm{L}$ of parathion, paraoxon, malathion or malaoxon for $8 \mathrm{~h}$. Intracellular levels of the phosphorylated proteins p-p38MAPK, p-STAT3 and p-c-Jun were evaluated using a Bioplex system. Data are calculated as $\%$ of control (indicated by dashed line) and are shown as mean \pm SEM. Asterisks indicate significant differences to the control $(* p<0.05 ; n=4$ samples from four different animals)

\section{Discussion}

Respiratory complications occur in many cases of severe organophosphate poisoning and are a leading cause of death after suicidal or accidental intoxication (Tsao et al. 1990; Hulse et al. 2014). There is increasing evidence that mechanisms other than AChE inhibition may contribute to the high toxicity of OP (Eyer et al. 2010; Xie et al. 2000), e.g. the formation of lung edema, tissue destruction and alterations in the immune response leading to an acute respiratory distress syndrome (Perkins et al. 2011; Lotti 2001). Therefore, toxic effects of parathion, malathion and their respective biotransformation products paraoxon and malaoxon, as representative OP, were investigated in rat PCLS.

\section{Effects of OP exposure on airway reactivity}

As inhibition of the AChE is generally seen as primary toxic mechanism of OP, the AChE inhibitory potential of the four investigated compounds in rat PCLS was assessed. PCLS contain viable airways surrounded by a smooth muscle layer, thus constriction of the airways can be provoked by stimulation with neurotransmitters like ACh (Wohlsen et al. 2003). The constriction is spontaneously reversible due to lung resident AChE activity, which results in relaxation of the airways. Airway response upon OP exposure has previously been studied to find novel treatment strategies in OP poisoning (Herbert et al. 2017, 2019; Wigenstam et al. 2021). Addition of the OP without ACh stimulation failed to induce airway constriction, most probably due to limited nervous stimulation in the PCLS. This was also observed in VX-exposed PCLS (Herbert et al. 2017; Wigenstam et al. 2021). We did not observe significant differences in maximum constriction of the airways between the four 
applied OP. However, in a PCLS study from Wigenstam et al. (2021), using a slightly different exposure scenario (ACh-OP-ACh instead of OP-ACh), nerve agent exposure in combination with ACh led to an increased bronchoconstriction in PCLS compared to ACh alone. The parent OP parathion and malathion failed to induce an inhibitory effect on airway relaxation, indicating that $\mathrm{AChE}$ activity is not impaired (Fig. 1A, C). In contrast, paraoxon and malaoxon significantly decreased airway relaxation in concentrations of 0.1 and $1 \mu \mathrm{mol} / \mathrm{L}$, respectively (Fig. 1B, D). These results underline the requirement of metabolic activation of thion-OP for substantial AChE inhibition (Eyer et al. 2003; Buratti and Testai 2005). Paraoxon shows a higher inhibitory potential than malaoxon, which is in line with inhibition of rat erythrocyte membrane $\mathrm{AChE}$ (second order inhibition rate constant; $2.72 \times 10^{6} \mathrm{M}^{-1} \mathrm{~min}^{-1}$ for paraoxon vs. $4.76 \times 10^{5} \mathrm{M}^{-1} \mathrm{~min}^{-1}$ for malaoxon). In addition, the inhibitory potential is well comparable to human erythrocyte membrane $\mathrm{AChE}$ (second order inhibition rate constant; $3.16 \times 10^{6} \mathrm{M}^{-1} \mathrm{~min}^{-1}$ for paraoxon vs. $4.74 \times 10^{5} \mathrm{M}^{-1} \mathrm{~min}^{-1}$ for malaoxon) pointing towards comparable inter-species inhibition data (unpublished data J. Tigges and F. Worek et al. (2020)). The current study nicely shows that AChEmediated airway response in PCLS is a suitable tool to analyze dose-dependent effects of OP.

\section{Effects of OP exposure on PCLS viability}

PCLS are frequently used to analyze cytotoxic effects to the lung without restriction to particular lung cell types (Neuhaus et al. 2018; Sauer et al. 2014). This is of special interest as it has been shown that OP cytotoxicity is dependent on the particular kind of lung cells used (Angelini et al. 2015). After exposure to OP, a decrease in viability, as well as an increase in LDH release was observed. Only parathion did not induce significant cytotoxic effects (Fig. 2A vs 2B-D). Thereby, decrease in viability and increase in LDH showed a good correlation for the investigated structurally different OP parathion, paraoxon, malathion and malaoxon. Although cytotoxicity of both oxon forms is stronger than that of the related thion-OP, malathion exposure led to a significant decrease in viability compared to the solvent control and an increase in LDH release (Fig. 2C). These findings are in line with observations in human neuronal cells (Bharate et al. 2010; Wang et al. 2019) and pulmonary cells (Angelini et al. 2015). As malaoxon has a much higher AChE inhibiting potency than malathion, a mode of action for cell injury which is different from AChE inhibition is highly likely. The cytotoxic potential is underlined by significantly decreased protein concentrations (Fig. 2E), indicating severe tissue injury (Sauer et al. 2014; Behrsing et al. 2013).

Cytotoxicity is induced at much higher concentrations (up to 5000 fold) than those inducing inhibition of airway relaxation. Therefore, these effects may occur mainly when the lung is directly exposed towards OP, for example after inhalation of nebulized pesticides or by aspiration of OP after suicidal ingestion. If the lung is exposed towards OP exclusively via the bloodstream, effects of AChE inhibition may be lethal before local toxic effects can develop. The parent compound malathion induced dose-dependent cytotoxicity while it failed to provoke a decrease in airway relaxation. Furthermore, malaoxon was more cytotoxic than paraoxon, although paraoxon showed stronger AChE inhibitory potential (effects on different toxicological endpoints summarized in Table 1). This further points towards a different mechanism than AChE inhibition, which is extensively discussed in the literature (Costa 2006; Eyer et al. 2010). It has been found that OP have the potential to bind to more than 50 different proteins in the mouse brain, possibly altering protein function, which may explain $\mathrm{AChE}$ independent effects. Interestingly, a particular OP binds only to specific proteins, which might be an indicator for different toxicological modes of action and characteristic effects of particular OP (Lockridge et al. 2005).

\section{Effects of OP exposure on inflammatory activation}

Epidemiological studies showed an increased rate of infections in the upper respiratory tract of workers chronically exposed to OP compared to a healthy control group (Hermanowicz and Kossman 1984) and animal studies have shown immunomodulatory effects after exposure to parathion or malathion (Liu et al. 2006; Proskocil et al. 2013; Abdo et al. 2021). PCLS are frequently used as model system for the investigation of substance-induced inflammatory activation indicated by an increased expression of inflammatory cytokines (Henjakovic et al. 2008). We, therefore, analyzed the cytokine expression in rat PCLS after OP exposure. Our results indicate that the cytokine expression in PCLS is highly dependent on the OP. While exposure to parathion and paraoxon caused an increase of the cytokines IL-6, GMCSF, VEGF and MIP-1 $\alpha$, malathion and malaoxon failed to induce such strong alterations in inflammatory response. Increased expression of these cytokines indicates induction of pulmonary inflammation, macrophage activation and acute lung injury (Fernando et al. 2014; Shibata et al. 2001; Voelkel et al. 2006). As the upregulated cytokines are

Table 1 Overview of organophosphate induced effects in PCLS

\begin{tabular}{lllll}
\hline & Parathion & Paraoxon & Malathion & Malaoxon \\
\hline Airway relaxation & - & ++ & - & + \\
Cytotoxicity & - & + & + & ++ \\
Inflammation & ++ & + & - & - \\
ROS & + & + & + & ++ \\
\hline
\end{tabular}


expressed by activated macrophages, it can be assumed that macrophages play an important role in OP-induced inflammation in PCLS. These suggestions are in line with data obtained from in vitro exposure of macrophage cell lines (Proskocil et al. 2019). Importantly, PCLS contain a mixture of different cells, of which only a portion is involved in immunological response, allowing a more realistic evaluation of inflammatory activation, which is an advantage over single cell-type macrophage cultures. As PCLS were prepared from rat lungs, inter-individual differences need to be considered. In the present study, we observed different basal immunological activation between animals, which necessitates normalization to the individual controls which is a well-known limitation in PCLS (Sauer et al. 2014).

\section{NfKB-signal transduction in OP poisoning}

Expression of the above mentioned cytokines is dependent on activation of the NF- $\mathrm{\kappa B}$ signal transduction pathway (Kiriakidis et al. 2003; Liu et al. 2017). In brief, activation of cytokine receptors, pattern recognition receptors or $\mathrm{T}$ - and B-cell receptors results in stimulation of the IкB kinase (IKK) complex, leading to phosphorylation and subsequent degradation of I $\mathrm{KB} \alpha$. Thereafter, the NF- $\kappa \mathrm{B}$ dimers p50/RelA and p50/c-Rel translocate to the nucleus, acting as transcription factor for the induction of target genes at the $\kappa B$ response element (Liu et al. 2017). To evaluate whether inflammatory activation induced by $\mathrm{OP}$ is NF- $\mathrm{\kappa B}$ dependent, the effects of an IKK- $\beta$ inhibitor on IL- 6 expression after parathion exposure were evaluated (Fig. 3E), as this combination has provoked the strongest response in the Bioplex screening (Fig. 3A). IL-6 expression was significantly decreased after co-incubation of parathion with the IKK- $\beta$ inhibitor, which demonstrates an activation of the NF- $\mathrm{KB}$ signal transduction pathway in response to parathion exposure. It has been found that the NF- $\mathrm{KB}$ signal transduction pathway is activated by parathion in differentiated human macrophages and that parent compounds show a stronger activation potential than their metabolites, which is in line with our observations of cytokine expression (Proskocil et al. 2019). The successful inhibition of inflammatory activation confirms PCLS as a potential model system to study the use of candidate therapeutics for treatment of pulmonary inflammation after OP exposure and may be a potential explanation for alterations of the immune system observed in OP-poisoned patients. Anti-inflammatory drugs (COX2 inhibitors) have been already used in an in vivo OP model (rat) (Chapman et al. 2019) and could be evaluated in PCLS.

\section{Effects of OP exposure on antioxidative defense}

Elevated levels of reactive oxygen species (ROS) like superoxide or hydrogen peroxide can cause substantial damage to cellular organelles, lipids, proteins and DNA which may result in apoptosis (Sies et al. 2017). Reduced GSH acts as intracellular antioxidant that is used by the glutathione peroxidase for detoxification of ROS. The oxidized GSSG is afterwards reduced to GSH by a glutathione reductase (Rahman et al. 2005). Antioxidative enzymes like SOD have a key role in antioxidant defense by eliminating intracellular superoxide (Afonso et al. 2007). In addition, cells that are under oxidative stress respond with the expression of antioxidative proteins like HO-1, which has tissue protective properties by oxidative cleavage of free heme groups (Ryter and Choi 2005).

Alterations of the antioxidative system were observed in patients after exposure to OP suggesting a role of ROS in OP poisoning (Banerjee et al. 1999; Seth et al. 2001). In PCLS, intracellular GSH levels can be used as marker for the induction of oxidative stress (Sauer et al. 2014). In the present study a significant decrease in intracellular GSH levels for all applied OP in concentrations below those inducing cytotoxic effects was observed (Fig. 4A). Reduced levels of intracellular GSH indicate a cellular reaction towards ROS in response to oxidative stress. Interestingly, the oxidized GSSG was only significantly upregulated after malaoxon exposure, indicating a stronger impairment of oxidative defense of malaoxon than the other OP (Fig. 4B). It has also been shown that loss of intracellular GSH is a mechanism that regulates redox signaling and cell death which may be an explanation for decreased GSH levels without an increase of GSSG (Franco and Cidlowski 2012). As decrease of GSH can be related to an increased biotransformation of OP by the glutathione-S-transferase (GST) (Fujioka and Casida 2007), GST activity in PCLS after OP exposure was analyzed. No significant changes in GST activity were observed, indicating that reduced GSH levels are not related to an increase in metabolic activity (Fig. 4C). Impairment of SOD activity seems to be not involved in OP-induced alterations of the antioxidative defense system (Fig. 4D). Expression of HO-1, indicating cellular response to oxidative stress, was significantly upregulated following parathion, malathion and malaoxon exposure, with malaoxon inducing the strongest effects (Fig. 4E). These findings further underline the diversity of OP in induction of antioxidative response and that malaoxon provokes a stronger alteration of the redox system than malathion, parathion or paraoxon. It has been shown that malathion induces oxidative stress in the rat brain that could be due to inhibition of the complex IV of the respiratory chain (Delgado et al. 2006). However, the exact mechanism leading to ROS generation after malaoxon exposure remains elusive.

As medical countermeasure, we analyzed whether preincubation of PCLS with the antioxidative GSH precursor NAC has an impact on OP-induced cytotoxicity. Viability 
after malaoxon but not after paraoxon exposure was significantly improved after pre-incubation with NAC (Fig. 5), indicating that malaoxon induced cytotoxicity is at least in part dependent on alterations of the redox system. Future studies could evaluate the therapeutic efficacy of antioxidative drugs such as vitamin $\mathrm{E}$ that were already evaluated in vivo (John et al. 2001).

\section{Effects of OP exposure on signaling pathway activation}

Mitogen activated protein kinase (MAPK) signaling pathways like the c-Jun N-terminal kinase (JNK), p38MAPK or extracellular signal regulated kinase (ERK) play an important role in a variety of cellular processes like cell differentiation, apoptosis and oxidative stress response (Morrison 2012). In our study we evaluated the intracellular levels of phosphorylated p38MAPK, Signal transducer and activator of transcription 3 (STAT3) and c-Jun as key players in the p38MAPK, ERK and JNK pathways, respectively. An increase in p38MAPK phosphorylation was observed for all investigated OP and was accompanied by a reduction in phosphorylation of STAT3 (Fig. 6). p38MAPK is activated in response to a variety of different noxious stimuli including UV, heat and cytokine stimulation. Phosphorylation results in transcription of target genes involved in cell cycle control and cell death (Morrison 2012). It has been shown that activation of p38MAPK in combination with a decreased activity of the ERK pathway (e.g. STAT3) is important for the induction of apoptosis (Xia et al. 1995) and that MAPK are involved in the toxicity of several OP (Farkhondeh et al. 2020). The JNK signal transduction pathway is involved in several cellular mechanisms including response towards oxidative stress (Ki et al. 2013; Kamata et al. 2005). Significant changes in c-Jun phosphorylation were only observed after malaoxon exposure, which is in line with the oxidative stress inducing potential of this OP (Figs. 4 vs. 6). The observed changes in activation of the investigated pathways underline the cytotoxic and oxidative stress inducing potential and it can be assumed that MAPK activation is involved in the observed toxic effects of OP in rat PCLS.

\section{Conclusions}

The OP parathion, malathion and their respective biotransformation products paraoxon and malaoxon induce distinct toxicological effects in PCLS. Effects of these OP on airway relaxation are well comparable with their effects on $\mathrm{AChE}$ inhibition. Induction of cytotoxic effects is mediated by much higher concentrations than functional impairment via $\mathrm{AChE}$ inhibition. Interestingly, OP showed different potency for inflammatory activation as well as for the disturbance of antioxidative response (summarized in Table 1). These results indicate that $\mathrm{OP}$ exert compound-specific toxic effects in rat lung tissue beyond AChE inhibition. PCLS are a valuable tool for the investigation of direct toxic effects (e.g. cytotoxicity or inflammatory activation) as well as for the analysis of tissue architecture and physiological response (airway relaxation), which offers unique possibilities to investigate multiple effects of OP exposure in a single tissue culture system. Future studies using PCLS may address the underlying mechanisms of non-AChE related effects by RNA expression, protein analysis and potential effects on other signaling pathways. In addition, the combined use of various precision cut tissue slices (e.g. lung, liver and kidney) might provide insights into effects of metabolic activation and detoxification.

Supplementary Information The online version contains supplementary material available at https://doi.org/10.1007/s00204-021-03186-X.

Funding Open Access funding enabled and organized by Projekt DEAL. This work was supported from the German Research Foundation (GRK 2338, Targets in Toxicology); project P02 to TW and FW; JT received a Ph.D. stipend in the GRK 2338.

\section{Declarations}

Conflict of interest The authors declare that they have no conflict of interest.

Open Access This article is licensed under a Creative Commons Attribution 4.0 International License, which permits use, sharing, adaptation, distribution and reproduction in any medium or format, as long as you give appropriate credit to the original author(s) and the source, provide a link to the Creative Commons licence, and indicate if changes were made. The images or other third party material in this article are included in the article's Creative Commons licence, unless indicated otherwise in a credit line to the material. If material is not included in the article's Creative Commons licence and your intended use is not permitted by statutory regulation or exceeds the permitted use, you will need to obtain permission directly from the copyright holder. To view a copy of this licence, visit http://creativecommons.org/licenses/by/4.0/.

\section{References}

Abdo W, Elmadawy MA, Abdelhiee EY, Abdel-Kareem MA, Farag A, Aboubakr M, Ghazy E, Fadl SE (2021) Protective effect of thymoquinone against lung intoxication induced by malathion inhalation. Sci Rep 11(1):2498. https://doi.org/10.1038/ s41598-021-82083-w

Afonso V, Champy R, Mitrovic D, Collin P, Lomri A (2007) Reactive oxygen species and superoxide dismutases: role in joint diseases. Jt Bone Spine 74(4):324-329. https://doi.org/10.1016/j.jbspin. 2007.02.002

Angelini DJ, Moyer RA, Cole S, Willis KL, Oyler J, Dorsey RM, Salem H (2015) The pesticide metabolites paraoxon and malaoxon induce cellular death by different mechanisms in cultured human pulmonary cells. Int J Toxicol 34(5):433-441. https://doi.org/10. $1177 / 1091581815593933$ 
Banerjee BD, Seth V, Bhattacharya A, Pasha ST, Chakraborty AK (1999) Biochemical effects of some pesticides on lipid peroxidation and free-radical scavengers. Toxicol Lett 107(1-3):33-47. https://doi.org/10.1016/S0378-4274(99)00029-6

Behrsing HP, Furniss MJ, Davis M, Tomaszewski JE, Parchment RE (2013) In vitro exposure of precision-cut lung slices to 2-(4-amino-3-methylphenyl)-5-fluorobenzothiazole lysylamide dihydrochloride (NSC 710305, Phortress) increases inflammatory cytokine content and tissue damage. Toxicol Sci 131(2):470-479. https://doi.org/10.1093/toxsci/kfs319

Bharate SB, Prins JM, George KM, Thompson CM (2010) Thionate versus Oxon: comparison of stability, uptake, and cell toxicity of $((14) \mathrm{CH}(3) \mathrm{O})(2)$-labeled methyl parathion and methyl paraoxon with SH-SY5Y cells. J Agric Food Chem 58(14):8460-8466. https://doi.org/10.1021/jf100976v

Buratti FM, Testai E (2005) Malathion detoxification by human hepatic carboxylesterases and its inhibition by isomalathion and other pesticides. J Biochem Mol Toxicol 19(6):406-414. https://doi.org/ 10.1002/jbt.20106

Chapman S, Grauer E, Gez R, Egoz I, Lazar S (2019) Time dependent dual effect of anti-inflammatory treatments on sarin-induced brain inflammation: suggested role of prostaglandins. Neurotoxicology 74:19-27. https://doi.org/10.1016/j.neuro.2019.05.006

Costa LG (2006) Current issues in organophosphate toxicology. Clinica Chimica Acta Int J Clin Chem 366(1-2):1-13. https://doi.org/10. 1016/j.cca.2005.10.008

Delgado EHB, Streck EL, Quevedo JL, Dal-Pizzol F (2006) Mitochondrial respiratory dysfunction and oxidative stress after chronic malathion exposure. Neurochem Res 31(8):1021-1025. https:// doi.org/10.1007/s11064-006-9111-1

Eddleston M, Eyer P, Worek F, Mohamed F, Senarathna L, von Meyer L, Juszczak E, Hittarage A, Azhar S, Dissanayake W, Sheriff MR, Szinicz L, Dawson AH, Buckley NA (2005) Differences between organophosphorus insecticides in human self-poisoning: a prospective cohort study. Lancet 366(9495):1452-1459. https://doi. org/10.1016/S0140-6736(05)67598-8

Eyer F, Meischner V, Kiderlen D, Thiermann H, Worek F, Haberkorn M, Felgenhauer N, Zilker T, Eyer P (2003) Human parathion poisoning. A toxicokinetic analysis. Toxicol Rev 22(3):143-163. https://doi.org/10.2165/00139709-200322030-00003

Eyer P, Worek F, Thiermann H, Eddleston M (2010) Paradox findings may challenge orthodox reasoning in acute organophosphate poisoning. Chem Biol Interact 187(1-3):270-278. https://doi.org/10. 1016/j.cbi.2009.10.014

Farkhondeh T, Mehrpour O, Buhrmann C, Pourbagher-Shahri AM, Shakibaei M, Samarghandian S (2020) Organophosphorus compounds and MAPK signaling pathways. Int J Mol Sci. https://doi. org/10.3390/ijms21124258

Fernando MR, Reyes JL, Iannuzzi J, Leung G, McKay DM (2014) The pro-inflammatory cytokine, interleukin-6, enhances the polarization of alternatively activated macrophages. PLoS ONE 9(4):e94188. https://doi.org/10.1371/journal.pone.0094188

Franco R, Cidlowski JA (2012) Glutathione efflux and cell death. Antioxid Redox Signal 17(12):1694-1713. https://doi.org/10.1089/ars. 2012.4553

Fujioka K, Casida JE (2007) Glutathione $S$-transferase conjugation of organophosphorus pesticides yields $S$-phospho-, $S$-aryl-, and $S$-alkylglutathione derivatives. Chem Res Toxicol 20(8):12111217. https://doi.org/10.1021/tx700133c

Fukuto TR (1990) Mechanism of action of organophosphorus and carbamate insecticides. Environ Health Perspect 87:245-254. https:// doi.org/10.1289/ehp.9087245

Henjakovic M, Sewald K, Switalla S, Kaiser D, Müller M, Veres TZ, Martin C, Uhlig S, Krug N, Braun A (2008) Ex vivo testing of immune responses in precision-cut lung slices. Toxicol Appl
Pharmacol 231(1):68-76. https://doi.org/10.1016/j.taap.2008. 04.003

Herbert J, Thiermann H, Worek F, Wille T (2017) Precision cut lung slices as test system for candidate therapeutics in organophosphate poisoning. Toxicology 389:94-100. https://doi.org/10.1016/j.tox. 2017.07.011

Herbert J, Thiermann H, Worek F, Wille T (2019) COPD and asthma therapeutics for supportive treatment in organophosphate poisoning. Clin Toxicol (philadelphia, Pa.) 57(7):644-651. https://doi. org/10.1080/15563650.2018.1540785

Hermanowicz A, Kossman S (1984) Neutrophil function and infectious disease in workers occupationally exposed to phosphoorganic pesticides: role of mononuclear-derived chemotactic factor for neutrophils. Clin Immunol Immunopathol 33(1):13-22. https:// doi.org/10.1016/0090-1229(84)90288-5

Holmstedt B (1959) Pharmacology of organophosphorus cholinesterase inhibitors. Pharmacol Rev 11:567-688

Hrabetz H, Thiermann H, Felgenhauer N, Zilker T, Haller B, Nährig J, Saugel B, Eyer F (2013) Organophosphate poisoning in the developed world - a single centre experience from here to the millennium. Chem Biol Interact 206(3):561-568. https://doi.org/ 10.1016/j.cbi.2013.05.003

Hulse EJ, Davies JOJ, Simpson AJ, Sciuto AM, Eddleston M (2014) Respiratory complications of organophosphorus nerve agent and insecticide poisoning. Implications for respiratory and critical care. Am J Respir Crit Care Med 190(12):1342-1354. https:// doi.org/10.1164/rccm.201406-1150CI

John S, Kale M, Rathore N, Bhatnagar D (2001) Protective effect of vitamin $\mathrm{E}$ in dimethoate and malathion induced oxidative stress in rat erythrocytes. J Nutr Biochem 12(9):500-504. https://doi.org/ 10.1016/S0955-2863(01)00160-7

Johnson J (1987) Species-related differences in the inhibition of brain acetylcholinesterase by paraoxon and malaoxon*1. Toxicol Appl Pharmacol 88(2):234-241. https://doi.org/10.1016/0041-008x(87) 90009-3

Kamat SR, Heera S, Potdar PV, Shah SV, Bhambure NM, Mahashur AA (1989) Bombay experience in intensive respiratory care over 6 years. J Postgrad Med 35(3):123-134

Kamata H, Honda S, Maeda S, Chang L, Hirata H, Karin M (2005) Reactive oxygen species promote TNF $\alpha$-induced death and sustained JNK activation by inhibiting MAP kinase phosphatases. Cell 120(5):649-661. https://doi.org/10.1016/j.cell.2004.12.041

Ki Y-W, Park JH, Lee JE, Shin IC, Koh HC (2013) JNK and p38 MAPK regulate oxidative stress and the inflammatory response in chlorpyrifos-induced apoptosis. Toxicol Lett 218(3):235-245. https://doi.org/10.1016/j.toxlet.2013.02.003

Kiriakidis S, Andreakos E, Monaco C, Foxwell B, Feldmann M, Paleolog E (2003) VEGF expression in human macrophages is NF-kappaB-dependent: studies using adenoviruses expressing the endogenous NF-kappaB inhibitor IkappaBalpha and a kinase-defective form of the IkappaB kinase 2. J Cell Sci 116(Pt 4):665-674. https://doi.org/10.1242/jcs.00286

Lauenstein L, Switalla S, Prenzler F, Seehase S, Pfennig O, Förster C, Fieguth H, Braun A, Sewald K (2014) Assessment of immunotoxicity induced by chemicals in human precision-cut lung slices (PCLS). Toxicol in Vitro 28(4):588-599. https://doi.org/ 10.1016/j.tiv.2013.12.016

Liberati TA, Randle MR, Toth LA (2010) In vitro lung slices: a powerful approach for assessment of lung pathophysiology. Expert Rev Mol Diagn 10(4):501-508. https://doi.org/10.1586/erm.10.21

Liu P, Song X, Yuan W, Wen W, Wu X, Li J, Chen X (2006) Effects of cypermethrin and methyl parathion mixtures on hormone levels and immune functions in Wistar rats. Arch Toxicol 80(7):449 457. https://doi.org/10.1007/s00204-006-0071-7 
Liu T, Zhang L, Joo D, Sun S-C (2017) NF- $\mathrm{B}$ signaling in inflammation. Signal Transduct Targeted Ther 2:17023. https://doi.org/10. 1038/sigtrans.2017.23

Liu G, Betts C, Cunoosamy DM, Åberg PM, Hornberg JJ, Sivars KB, Cohen TS (2019) Use of precision cut lung slices as a translational model for the study of lung biology. Respir Res 20(1):162. https:// doi.org/10.1186/s12931-019-1131-x

Lockridge O, Duysen EG, Voelker T, Thompson CM, Schopfer LM (2005) Life without acetylcholinesterase: the implications of cholinesterase inhibitor toxicity in AChE-knockout mice. Environ Toxicol Pharmacol 19(3):463-469. https://doi.org/10.1016/j. etap.2004.12.008

Lotti M (2001) Clinical toxicology of anticholinesterase agents in humans. In: Krieger RI (ed) Handbook of pesticide toxicology, vol 2, 2nd edn. Academic Press, San Diego, pp 1043-1085

Martin C, Uhlig S, Ullrich V (1996) Videomicroscopy of methacholine-induced contraction of individual airways in precision-cut lung slices. Eur Respir J 9(12):2479-2487. https://doi.org/10. 1183/09031936.96.09122479

Mew EJ, Padmanathan P, Konradsen F, Eddleston M, Chang S-S, Phillips MR, Gunnell D (2017) The global burden of fatal self-poisoning with pesticides 2006-15: systematic review. J Affect Disord 219:93-104. https://doi.org/10.1016/j.jad.2017.05.002

Morrison DK (2012) MAP kinase pathways. Cold Spring Harb Perspect Biol. https://doi.org/10.1101/cshperspect.a011254

Nambiar MP, Gordon RK, Rezk PE, Katos AM, Wajda NA, Moran TS, Steele KE, Doctor BP, Sciuto AM (2007) Medical countermeasure against respiratory toxicity and acute lung injury following inhalation exposure to chemical warfare nerve agent VX. Toxicol Appl Pharmacol 219(2-3):142-150. https://doi.org/10.1016/j. taap.2006.11.002

Neuhaus V, Danov O, Konzok S, Obernolte H, Dehmel S, Braubach P, Jonigk D, Fieguth H-G, Zardo P, Warnecke G, Martin C, Braun A, Sewald K (2018) Assessment of the cytotoxic and immunomodulatory effects of substances in human precision-cut lung slices. J vis Exp. https://doi.org/10.3791/57042

Perkins MW, Pierre Z, Rezk P, Song J, Oguntayo S, Morthole V, Sciuto AM, Doctor BP, Nambiar MP (2011) Protective effects of aerosolized scopolamine against soman-induced acute respiratory toxicity in guinea pigs. Int J Toxicol 30(6):639-649. https://doi. org/10.1177/1091581811415874

Peter JV, Sudarsan TI, Moran JL (2014) Clinical features of organophosphate poisoning: a review of different classification systems and approaches. Indian J Crit Care Med 18(11):735-745. https:// doi.org/10.4103/0972-5229.144017

Proskocil BJ, Bruun DA, Jacoby DB, van Rooijen N, Lein PJ, Fryer AD (2013) Macrophage TNF- $\alpha$ mediates parathion-induced airway hyperreactivity in guinea pigs. Am J Physiol Lung Cell Mol Physiol 304(8):L519-L529. https://doi.org/10.1152/ajplung. 00381.2012

Proskocil BJ, Grodzki ACG, Jacoby DB, Lein PJ, Fryer AD (2019) Organophosphorus pesticides induce cytokine release from differentiated human THP1 cells. Am J Respir Cell Mol Biol 61(5):620-630. https://doi.org/10.1165/rcmb.2018-0257OC

Rahman I, Biswas SK, Jimenez LA, Torres M, Forman HJ (2005) Glutathione, stress responses, and redox signaling in lung inflammation. Antioxid Redox Signal 7(1-2):42-59. https://doi.org/10. 1089/ars.2005.7.42

Russel WM, Burch RL (1959) The principles of humane experimental technique. Methuen, London

Ryter SW, Choi AMK (2005) Heme oxygenase-1: redox regulation of a stress protein in lung and cell culture models. Antioxid Redox Signal 7(1-2):80-91. https://doi.org/10.1089/ars.2005.7.80
Sauer UG, Vogel S, Aumann A, Hess A, Kolle SN, Ma-Hock L, Wohlleben W, Dammann M, Strauss V, Treumann S, Gröters S, Wiench K, van Ravenzwaay B, Landsiedel R (2014) Applicability of rat precision-cut lung slices in evaluating nanomaterial cytotoxicity, apoptosis, oxidative stress, and inflammation. Toxicol Appl Pharmacol 276(1):1-20. https://doi.org/10.1016/j.taap.2013. 12.017

Seth V, Banerjee BD, Bhattacharya A, Pasha ST, Chakravorty AK (2001) Pesticide induced alterations in acetylcholine esterase and gamma glutamyl transpeptidase activities and glutathione level in lymphocytes of human poisoning cases. Clin Biochem 34(5):427429. https://doi.org/10.1016/S0009-9120(01)00232-6

Shibata Y, Berclaz P-Y, Chroneos ZC, Yoshida M, Whitsett JA, Trapnell BC (2001) GM-CSF regulates alveolar macrophage differentiation and innate immunity in the lung through PU.1. Immunity 15(4):557-567. https://doi.org/10.1016/S1074-7613(01)00218-7

Sies H, Berndt C, Jones DP (2017) Oxidative stress. Annu Rev Biochem 86:715-748. https://doi.org/10.1146/annurev-bioch em-061516-045037

Travaglini KJ, Nabhan AN, Penland L, Sinha R, Gillich A, Sit RV, Chang S, Conley SD, Mori Y, Seita J, Berry GJ, Shrager JB, Metzger RJ, Kuo CS, Neff N, Weissman IL, Quake SR, Krasnow MA (2020) A molecular cell atlas of the human lung from singlecell RNA sequencing. Nature 587(7835):619-625. https://doi.org/ 10.1038/s41586-020-2922-4

Tsao TC, Juang YC, Lan RS, Shieh WB, Lee CH (1990) Respiratory failure of acute organophosphate and carbamate poisoning. Chest 98(3):631-636. https://doi.org/10.1378/chest.98.3.631

Voelkel NF, Vandivier RW, Tuder RM (2006) Vascular endothelial growth factor in the lung. Am J Physiol Lung Cell Mol Physiol 290(2):L209-L221. https://doi.org/10.1152/ajplung.00185.2005

Wang Y, Kim B, Walker A, Williams S, Meeks A, Lee Y-J, Seo SS (2019) Cytotoxic effects of parathion, paraoxon, and their methylated derivatives on a mouse neuroblastoma cell line NB41A3. Fundam Toxicol Sci 6(2):45-56. https://doi.org/10.2131/fts.6.45

Wigenstam E, Forsberg E, Bucht A, Thors L (2021) Efficacy of atropine and scopolamine on airway contractions following exposure to the nerve agent VX. Toxicol Appl Pharmacol 419:115512. https://doi.org/10.1016/j.taap.2021.115512

Wohlsen A, Martin C, Vollmer E, Branscheid D, Magnussen H, Becker WM, Lepp U, Uhlig S (2003) The early allergic response in small airways of human precision-cut lung slices. Eur Respir J 21(6):1024-1032. https://doi.org/10.1183/09031936.03.00027502

Worek F, Thiermann H, Wille T (2020) Organophosphorus compounds and oximes: a critical review. Arch Toxicol 94(7):2275-2292. https://doi.org/10.1007/s00204-020-02797-0

Xia Z, Dickens M, Raingeaud J, Davis RJ, Greenberg ME (1995) Opposing effects of ERK and JNK-p38 MAP kinases on apoptosis. Science 270(5240):1326-1331. https://doi.org/10.1126/scien ce. 270.5240 .1326

Xie W, Stribley JA, Chatonnet A, Wilder PJ, Rizzino A, McComb RD, Taylor P, Hinrichs SH, Lockridge O (2000) Postnatal developmental delay and supersensitivity to organophosphate in genetargeted mice lacking acetylcholinesterase. J Pharmacol Exp Ther 293(3):896-902

Publisher's Note Springer Nature remains neutral with regard to jurisdictional claims in published maps and institutional affiliations. 